\title{
Exogenous Shocks, Foreign Aid, and Civil War
}

\author{
Burcu Savun and Daniel C. Tirone
}

\begin{abstract}
The recent civil war literature suggests that negative economic shocks in low-income countries increase the risk of civil war. Foreign aid can be an effective conflict-prevention tool in times of severe economic conditions. Aid cushions government spending from the downward pressures of economic shocks, providing recipient governments with resources they can use to make rebellion a less attractive option for aggrieved domestic groups. Using Official Development Assistance (ODA) data covering 1990 through 2004, we find that foreign aid appears to be a useful tool for preventing civil wars in the wake of negative economic shocks, and as such aid should be assessed by donors with these conflict-suppressing aspects in mind.
\end{abstract}

One of the most robust correlates of civil war onset is income. Countries with low income per capita are more prone to civil wars than others. ${ }^{1}$ Recent findings also suggest that negative economic shocks are important predictors of civil war onset. ${ }^{2}$ Presumably, negative shocks increase the risk of civil war by temporarily decreasing the opportunity cost of fighting and increasing the level of economic grievances in society. Since low-income countries are particularly vulnerable to declines in global export prices, ${ }^{3}$ one might surmise that steep declines in export prices would have especially harmful effects in these countries. This raises the question of what might be done to mitigate the conflict-generating effects of unexpected economic shocks in low-income countries.

Foreign aid can be a particularly effective conflict-prevention measure in times of negative economic shock. Major economic crises usually put pressure on governments to reduce their spending, particularly in low-income countries. ${ }^{4}$ Reduc-

A previous version of this article was presented at the annual meeting of the Peace Science Society (International), 20-22 November 2009, Chapel Hill, N.C. We thank Scott Cook and Joseph Gallagher for research assistance and David Bearce, Scott Cook, Daniela Donno, Michael Findley, Nehemia Geva, Chuck Gochman, Julia Gray, Jude Hays, Michael Koch, Quan Li, Michaela Mattes, Irfan Nooruddin, Pat Regan, and Richard Stoll for useful comments and suggestions.

1. See Fearon and Laitin 2003; Collier and Hoeffler 2004; and Hegre and Sambanis 2006.

2. See Hegre and Sambanis 2006; Fearon 2008; Miguel, Satyanath, and Sergenti 2004; Brückner and Ciccone 2010; Chassang and Padró i Miguel 2009; and Savun and Cook 2010.

3. Wibbels 2006.

4. Ibid.

International Organization 66, Summer 2012, pp. 363-93

(C) 2012 by The IO Foundation.

doi:10.1017/S0020818312000136 
tions in government spending tend to exacerbate economic losses and grievances created by the shock. However, aid can decrease the pressure on the government to cut its spending by providing an exogenous pool of resources and thereby prevent an already bad situation from getting worse.

What is important for our argument is that at times of severe economic shock, governments face a heightened risk of civil war. If a pool of economic resources, such as foreign aid, is available, rational leaders are likely to use this resource to avert attacks on the regime. Even a corrupt dictator might be inclined to use aid to maintain the level of government spending if doing so will reduce threats to the regime.

This article makes several important contributions to both the civil war and foreign aid literatures. First, it explores the utility of foreign aid as a conflictprevention tool in low-income countries shaken by exogenous economic shocks. Because civil wars are more frequent, more deadly, and more difficult to resolve than interstate wars, ${ }^{5}$ the adoption of effective conflict-prevention and resolution tools are of particular importance. Second, there has been increasing attention in recent years to the need for foreign aid. For example, in 2005, the Group of Eight (G8) countries pledged to double their allocation of aid to Africa from \$25 billion to $\$ 50$ billion per year. ${ }^{6}$ A standing question has always asked how effective foreign aid is. Scholars have traditionally studied the effect of aid on the economic development and democratization of recipient countries. ${ }^{7}$ It would seem reasonable to ask whether aid also has discernible effects on domestic political stability. By exploring the relationship between foreign aid and the risk of civil war, we seek to broaden our understanding of aid's efficacy. This is a matter of both scholarly and policy relevance. If foreign aid has peace-inducing consequences, the international community has additional incentive to increase the level of foreign assistance.

We begin by developing our theoretical argument. First, we discuss how negative economic shocks increase the risk of conflict. Next, we explain how foreign aid can mitigate the deleterious effects of these shocks. Following this, we describe our research design and then test our argument using Organization for Economic Cooperation and Development (OECD) Official Development Assistance (ODA) data covering 1990 through 2004. We show that aid reduces the risk of civil conflict in countries that experience major global price shocks, recognizing that the effect is conditional upon a country's vulnerability to the shock. We conclude the article by discussing our key argument and highlighting avenues for future research.

5. Fearon and Laitin 2003.

6. Richard W. Stevenson, "8 Leaders Hail Steps on Africa and Warming," New York Times (Internet ed.), 9 July 2005.

7. See Boone 1996; Burnside and Dollar 2000; Dunning 2004; Finkel, Pérez-Liñán, and Seligson 2007; Kosack and Tobin 2006; Schraeder, Hook, and Taylor 1998; and Wright 2009. 


\section{Shocks, Government Response, and Civil War}

Extant research identifies the existence of a strong cross-sectional association between low income and civil war. Civil war scholars have proffered different explanations for this. One explanation emphasizes the "opportunity cost" of engaging in rebellion. Poor people do not have to give up much to join a rebellion and hence the risk of conflict is higher in low-income countries. ${ }^{8}$

An alternative explanation, offered by Fearon and Laitin, is that low income can be indicative of a "weak state," that is, a state lacking sufficient resources to undertake the necessary counterinsurgency measures to deter rebellion. ${ }^{9}$ Fearon expands this logic and argues that low-income countries are more prone to extortion/taxation by rebels because physical capital is less mobile and the level of human capital is lower in poor countries compared to rich countries. Therefore, it is easier for the rebel groups to finance a rebellion in low-income countries. ${ }^{10}$

If low-income countries are prone to conflict because of their limited counterinsurgency capabilities and the low levels of human capital, one way foreign aid could reduce the risk of conflict is by bolstering economic growth. ${ }^{11}$ As the economy of a country grows, more resources become available to invest in infrastructure, human capital, and military training. However, the relationship between aid and growth can be tenuous. There is no scholarly consensus on the extent to which foreign aid spurs growth in aid recipient countries. ${ }^{12}$ Clearly, aid is unlikely to have any discernible effect on civil war if it does not generate growth in the first place - and even if it does lead to economic development, this positive effect is usually not observed until some time after the aid is disbursed.

We argue that although foreign aid may not be generally effective in "rescuing" chronically poor states from poverty, it can still help low-income states maintain domestic peace when the risk of civil war is especially heightened. Our argument is based on the recent observation that civil wars are more likely to occur when countries are hit by negative economic shocks, such as sharp drops in global commodity prices. ${ }^{13}$

A country's vulnerability to global price shocks is a function of three factors: (1) the size of the shocks, (2) its exposure to the shocks, and (3) its resiliencethat is, its capacity to manage the shocks. ${ }^{14}$ The nature of the economy of lowincome countries makes it particularly difficult for the governments to protect

8. Collier and Hoeffler 2004.

9. Fearon and Laitin 2003.

10. Fearon 2008.

11. Collier and Hoeffler 2002.

12. See Boone 1996; Easterly 2003; Hansen and Tarp 2000; Hudson and Mosley 2001; Burnside and Dollar 2000; Flores and Nooruddin 2009; Kosack and Tobin 2006; and Bearce and Tirone 2010.

13. See Hegre and Sambanis 2006; Fearon 2008; Brückner and Ciccone 2010; Chassang and Padró i Miguel 2009; and Miguel, Satyanath, and Sergenti 2004.

14. Combes and Guillaumont 2002. 
themselves against the deleterious effects of drops in global commodity prices. Low-income countries tend to specialize in the export of a few products-mostly agricultural products or raw materials, which are shown to be highly sensitive to price fluctuations. ${ }^{15}$ Diversification can protect economies from shocks, but lowincome countries are relatively less diversified and hence more vulnerable to market fluctuations compared to wealthy nations. Therefore, when there is a decline in the price of agricultural commodities and/or raw materials in the global markets, the economies of low-income countries tend to be hit harder than other economies.

Low-income countries are also more affected by shocks because of constraints on their governments' ability to manage economic crises; that is, low-income countries are less resilient to shocks compared to high-income countries. When faced with similar declines in their revenues due to an economic downturn, governments in OECD countries often try to expand, rather than contract, government spending to engage in countercyclical demand management. They do so with the expectation that such increases will reduce the magnitude and duration of the economic downturn, in line with Keynesian economic theory. However, low-income countries' ability to engage in similar types of government policies is limited. When faced with an economic crisis, leaders of low-income countries are under greater pressure from international capital to adopt procyclical economic policies, such as reduction in government spending. ${ }^{16}$ The necessity of adopting procyclical policies during an economic crisis mostly lies in the limited supply of credit. Even in good times, these countries are considered high risk for lending and investment. ${ }^{17}$ The presence of an economic shock only diminishes their already tenuous prospects of receiving loans. In bad times, many low-income countries cannot borrow or else they borrow at high interest rates. Therefore, they have a more difficult time engaging in deficit spending and hence are pressured to cut expenditures. ${ }^{18}$

Spending cuts by governments of low-income countries in the wake of an exogenous shock further contract the economy, exacerbating reductions in income and aggravating the economic plight of the public. As the government reduces its expen-

15. Wibbels 2006.

16. See Alesina, Campante, and Tabellini 2008; Gavin and Perotti 1997; Talvi and Végh 2005; and Wibbels 2006.

17. Reinhart and Rogoff 2004.

18. Our explanation for why low-income countries tend to engage in procyclical policies in the times of economic distress emphasizes the constraints of the international market. This does not mean that domestic factors do not play a role in a government's decision on how to respond to an economic crisis. Indeed, domestic-level explanations have been the more prominent approach in explaining developing countries' responses to international markets. See Rudra 2002; Wibbels and Arce 2003; and Kaufman and Segura-Ubiergo 2001. However, even in a domestic politics approach, we would still expect domestic leaders in low-income countries to try to avoid higher debt and adopt a more austere fiscal policy. The reason is that debt burdens have fairly uniform distributional consequences for the debtor nation and hence threaten the interests of the strong domestic classes in the society. The evidence suggests that looming deficits leads to capital flights as well as exchange rate volatility in lowincome countries (Wibbels 2006). 
ditures, the amount of its contribution to domestic economic production decreases. Some domestic firms may lose government contracts, and private- and publicsector employees may be laid off. This not only increases unemployment but also produces downward pressure on wages as the pool of employment seekers increases and private consumption decreases.

Economic shocks and consequent cuts in government spending also negatively affect the domestic political stability of a country. When a country is hit by an economic crisis, wages drop temporarily, and the opportunity cost of engaging in a conflict declines. ${ }^{19}$ That is, what an individual has to give up to join a rebellion is lower during an economic crisis than at other times. However, since economic shocks are generally transient, the future value of the aggregate economy (total spoils) does not diminish as much as the current costs of fighting. ${ }^{20}$ Therefore, expecting that when the shock is over the spoils of the war will be valuable, domestic groups choose to fight today when returns to labor are low enough that recruiting for the war effort is easier.

Adverse economic shocks can also affect the level of what Levi calls "quasivoluntary compliance," where the government buys the support of the populace by providing public services and social transfers. ${ }^{21}$ By spending resources on goods and services beneficial to the public, the government keeps the populace content and the level of grievances low. ${ }^{22}$ During an economic crisis, governments' ability to maintain quasi-voluntary compliance is adversely affected as there are fewer available resources to be distributed. This in turn increases the level of grievances in the society. Nooruddin and Chhibber note that when "fiscal space" is low-when the government's income is close to its nondiscretionary spending commitments-it leaves little room for the introduction of new programs aimed at gaining public support for the sitting government. ${ }^{23}$ In such situations, voters will be more likely to turn their support to the opposition.

The link between government spending in the presence of economic shocks and conflict onset follows a similar logic. Shocks reduce the fiscal space and constrain the government's ability to provide the goods and services desired by the public. While in democracies the ensuing discontent may be expressed through the ballot box, in some situations groups may feel that the electoral process is not sufficient. Given that aggrieved groups are more willing to pick up arms against their governments than groups with a low level of grievances, ${ }^{24}$ the increase in grievances that arises due to government spending cuts raises the risk of a civil conflict. In his study of civil wars in Africa, Azam reaches a similar conclusion: "the occur-

19. Chassang and Padró i Miguel 2009.

20. Ibid.

21. Levi 2006, 6-7. We use the terms social spending, welfare spending, public goods provision, and social transfers interchangeably.

22. Levi 2006.

23. Nooruddin and Chhibber 2008.

24. Gurr 1970. 
rence of civil conflict in Africa is intimately related to the failure of governments to deliver the type of public expenditure that the people want, i.e., with a strong redistributive component such as health and education." 25

The diffuse scope of government spending is also a key component of the economic shock and conflict link. Economic shocks may occur in only a few specific sectors, in which case the general public may be directly unaffected by the economic downturn. However, since government spending programs draw on the aggregated revenues of the government, which are drawn in part from the entire national economy, shocks in a particular sector may translate into spending cuts that affect a significantly larger portion of the population. Therefore, just as an economic shock that decreases the fiscal space of a government may turn into a national electoral loss, an economic shock in a particular economic sector (or sectors) may have a far larger impact on the larger population through its effect on overall government revenues.

The negative effect of cuts in spending on public discontent is also magnified during crises because the demands for social welfare would be at their highest during periods of economic distress. ${ }^{26}$ Besides losing domestic support, such cuts could also increase domestic economic grievances aimed at government. This can create an opportunity for domestic conflict entrepreneurs to capitalize on these grievances and the newly created void in social welfare created by the government retrenchment.

The surge in the level of violence in Colombia in the late 1990s illustrates how rebel groups can take advantage of government weakness in times of economic shocks. Colombia faced a long-standing domestic insurgency in the form of the FARC and ELN rebel groups. The conflict intensified in the late 1990s, however, in part due to a drastic decline in coffee prices. ${ }^{27}$ Colombia, a large coffee exporter, was severely affected by the downturn and the government was forced to reduce social spending. Since "Colombia's main social assistance programs were illequipped to offer adequate countercyclical protection to those most affected by the (recent) crisis," 28 the rebel groups stepped into the void to win the favor of Colombians, particularly the coffee farmers. In addition to receiving wages, "all FARC members are given food and clothing, and interviews with ex-combatants indicate that this can serve as an impetus for joining the guerillas during economic downturns." ${ }^{29}$ In the battle between the government and rebels, the rebels used the economic downturn to their advantage, while the government, facing domestic economic losses and without financial aid to buttress expenditures, was largely unable to counter.

\author{
25. Azam 2001, 442. \\ 26. See Vreeland 2003; and Nooruddin and Simmons 2006. \\ 27. Dube and Vargas 2008. \\ 28. Giugale, Lafourcade, and Luff 2003, 714. \\ 29. Dube and Vargas 2008, 10.
}


In addition to decreasing the opportunity cost of fighting and increasing economic grievances, economic shocks can increase the risk of civil war by decreasing a state's deterrence capacity. A state's level of military and police spending can affect the risk of civil war in a number of ways. First, a strong military deters threats from rebels since the probability of military victory is low. Second, a strong military and police force can help the government maintain the rule of law and ensure that citizens do not feel that their physical safety is threatened. If the public does not feel safe, it may be more likely to join rebel groups. By reducing the amount of resources available to the government, economic shocks can reduce the government's capacity to fend off domestic threats. This, in turn, emboldens potential rebels to challenge the government. ${ }^{30}$

In sum, negative economic shocks put states in a precarious situation. By causing a temporary decrease in the opportunity cost of fighting, they increase incentives to fight. Additionally, shocks reduce the government's fiscal space and hence constrain its ability to maintain the benefits of peace (such as the provision of public goods), which in turn opens a window of opportunity for the opposition to mobilize economically aggrieved individuals. Finally, negative shocks increase the risk of conflict by weakening the state and emboldening potential rebels to challenge the government.

\section{Foreign Aid, Government Spending, and Civil War}

The effectiveness of foreign aid in stimulating economic growth in recipient countries has long been debated but no scholarly consensus has emerged on either theoretical or empirical grounds. Recently, scholars have argued that the effectiveness of aid is influenced by the economic conditions faced by recipient countries. ${ }^{31} \mathrm{In}$ particular, aid is most effective in countries that often experience commodity price volatility. Aid can attenuate growth-dampening effects of negative economic shocks in two ways. First, aid can act like "insurance" if it is made contingent on the realization of economic shocks. If aid is responsive, it can be used to offset the realized costs of shocks on the economy. However, the fact that aid decisions are usually slow and it may take years before aid is actually disbursed make aid unlikely to respond to shocks in time. ${ }^{32}$ A more plausible suggested mechanism by which aid may sustain growth in times of economic shocks is by making the country's economy more resilient. Aid can make a country more resilient to economic shocks

30. Although this argument has theoretical appeal, Collier and Hoeffler's 2007 finding that increased military spending does not always have a deterrent effect makes this mechanism relatively weak compared to the first two.

31. See Combes and Guillaumont 2002; Guillaumont and Chauvet 2001; Collier and Dehn 2001; and Collier and Goderis 2009a.

32. Collier and Goderis 2009a, 430. 
by providing liquidity, financing investments, and reducing the economy's exposure to sharp falls in import levels. ${ }^{33}$

Foreign aid also can be an important means for coping with political instability generated by negative economic shocks. Collier and Hoeffler show that although aid has no direct effect on the risk of civil conflict, it can reduce conflict indirectly by stimulating economic growth and reducing primary commodity exports as a share of gross domestic product (GDP) in recipient countries. ${ }^{34}$ This means that to the extent aid induces growth and/or reduces a country's dependence on primary commodity exports, its indirect effects on conflict can be realized. However, this can be a tenuous and lengthy process considering that aid's ability to bring about either change is largely a function of internal and external macroeconomic conditions and policies..$^{35}$

Alternatively, the relationship between aid and conflict may not require a long time to take effect nor rely on the existence of growth-enhancing economic conditions. Aid may attenuate the likelihood of conflict in the wake of economic downturns by "augmenting" government budgets. In particular, foreign aid can help recipient countries stave off conflict by reducing the pressure to cut spending during times of economic crisis. Foreign aid buffers government revenues from the domestic economic downturn, which in turn helps governments maintain their preshock level of spending or at least keep the magnitude of decreases in spending lower than they may otherwise be. ${ }^{36}$ Therefore, governments that receive foreign economic assistance should be in a better position to deal with the deleterious effects of economic crises than those that do not. ${ }^{37}$

Governments obtain their revenues primarily from three sources: taxation, borrowing, and aid inflows. ${ }^{38}$ Government revenues associated with taxation decline when domestic economic activity declines and governments in low-income coun-

33. See Collier and Goderis 2009a; and Guillaumont and Chauvet 2001.

34. Collier and Hoeffler 2002.

35. See, as an example, Burnside and Dollar 2000.

36. In addition to augmenting the government's budget, foreign aid can mitigate the postshock risk of conflict by assisting governments to reallocate resources among domestic groups. For example, domestic leaders can shift aid monies into public goods spending and away from infrastructure after economic downturns to reduce public grievances. The government's objective is to minimize the risk of rebellion while reallocating aid monies to groups that are most affected by economic crisis. The optimal reallocation of aid would be achieved when the marginal propensities to rebel (the change in the likelihood that a group rebels given a unit increase in its aid allocation) are equated across groups. However, we do not expect the reallocation mechanism to be utilized in all situations. Not all countries would necessarily need to adjust the distribution of their domestic spending to fend off domestic conflict. Although for many countries this would be a viable option, for countries whose leaders believe that the spending profile has already been calibrated to meet the demands of their domestic constituency, the primary challenge is not the distribution of spending, but the overall level of spending. That is, domestic leaders may not feel a need to divert funds from one purpose to another; rather, they may be worried about having to cut back spending in the face of a shock-induced revenue crisis.

37. Miguel 2007, 56-57, similarly suggests that foreign aid can be used to mitigate sharp income fluctuations that generate support for rebel groups in less developed countries.

38. Goode 1984. 
tries have a limited ability to borrow on international markets. Taken together, taxation and borrowing force procyclical responses to economic crisis in lowincome countries.

The third channel, aid inflows, can help reduce the pressure for the procyclical responses to economic shock. This is true because aid is largely decoupled from the short-term economic performance of the recipient. Aid's ability to cushion government spending from the downward pressures of economic shocks stems from its ability to provide an alternative to tax revenue. Therefore, even if current aid flows are already built into the existing level of government spending, aid still shields recipients from the deleterious effects of shocks by reducing the correlation between domestic economic performance and changes in government expenditures.

Morrison in his recent International Organization article discusses a similar stabilizing effect of foreign aid. ${ }^{39} \mathrm{He}$ theorizes that in nondemocracies, aid provides leaders with additional revenue that can be used to appease the dissatisfied public and thereby prevent regime change or revolution. ${ }^{40}$ Morrison shows that a surge in the level of aid (nontax revenue) is associated with an increase in social spending in dictatorships. By improving leaders' ability to buy off the opposition, aid reduces the probability of regime transition and thereby enforces regime stability both in democracies and autocracies. ${ }^{41}$

Our argument does not necessitate that aid flows increase dampen the risk of conflict arising from economic shock. What is important is whether a state is an aid recipient prior to the shock. ${ }^{42}$ Unlike natural disasters, which generate large amounts of publicity and lead to increases in humanitarian aid, commodity price shocks are less "photogenic" events, meaning governments are often left "on their own" to deal with the consequences. ${ }^{43}$ Additionally, because there is usually a significant time lag between the decision to allocate aid and the actual disbursement, economic aid is unlikely to respond to economic shocks in a timely manner. ${ }^{44}$

The Zambian copper crisis in 2008 illustrates how governments can use aid to keep the risk of rebellion low during economic downturns. In the early 2000s, Zambia was one of the poorest countries in the world, ranking 164th out of 182 countries on the United Nation's Human Development Index. ${ }^{45}$ Poverty and dis-

39. Morrison 2009.

40. In democracies, aid enables leaders to lower the tax burden of the elites, who constitute a threat to the regime. Ibid., 113.

41. Ibid., 109. Acemoglu and Robinson 2006 also show that during economic recessions it is easier for the elites to buy off the poor through temporary redistribution and thereby prevent democratization.

42. Kono and Montinola 2009 argue that autocrats tend to stockpile aid over the years and use these resources later to offset future negative shocks.

43. Collier et al. 2003, 132-33.

44. Collier and Goderis 2009a. We do not assume that aid revenues are necessarily stable over time. Aid revenues can be volatile and such volatility is likely to increase the risk of conflict in recipient countries. Nielsen et al. 2011.

45. United Nations Development Programme 2009. 
ease were endemic, with 59 percent of the population living beneath the poverty line and more than 14 percent estimated to have HIV. ${ }^{46}$ Yet, there was evidence that economic conditions were beginning to change for the better. Beginning in 2000, Zambia experienced eight consecutive years of positive growth - the longest period of sustained growth in the country since the early $1970 \mathrm{~s} .{ }^{47}$ The same factor-copper exports-that precipitated this period of growth has been responsible for much of Zambia's economic hardships. As White and Edstrand state, "Zambia[n] development is inextricably linked to copper," accounting for more than 70 percent of its export earnings ${ }^{48}$ Copper mining is the largest source of employment in most regions of the country and the main generator of foreign direct investment. Dependence on a "mining-dominated economy" makes Zambia highly vulnerable to changes in copper prices. ${ }^{49}$

When the recent global financial crisis hit, the effects on Zambia were severe. The troubles, which began with increases in food and fuel prices, reached a critical level when copper prices collapsed late in $2008 .^{50}$ Over the course of 2008, the price of copper was halved, "transmit[ing] a major shock to the country." ${ }^{1}$ The centrality of the copper industry was so pronounced that for every job lost in the formal mining sector, another twenty jobs were lost in services, suppliers, and the informal economy. ${ }^{52}$ The impact of these losses was further magnified when direct investments from Europe and the United States decreased dramatically. This situation typified the boom-bust cycle that often characterizes Zambia's economy.$^{53}$ Further adding to domestic uncertainty was the unexpected death of the popular president, Levy Mwanawasa, in August 2008.

Taken together, the economic and political conditions in Zambia threatened to unravel its tenuous domestic stability. ${ }^{54}$ According to a report by Caleb Fundanga, a governor of the Bank of Zambia, there were concerns that the copper shock would collapse national income and "reduce people['s] capability to meet their basic social and human needs such as food, health, shelter and education. The likely consequence over time is social upheaval." ${ }^{55}$ These predictions seemed to come to pass as protests emerged in response to mine closures. In particular, the closing of a small mine in Luanshya — caused by the recession— triggered a pro-

46. Green 2009.

47. Ndulo et al. 2009.

48. White and Edstrand 1998, 223.

49. World Bank 2002.

50. Ndulo et al. 2009.

51. Ibid., 14.

52. Green 2009.

53. Collier and Gunning 1999.

54. In our models, a country with similar characteristics to Zambia has a 2 percent baseline probability of a conflict onset. An economic shock to a sector that accounts for more than 80 percent of the country's economy raises the risk of conflict to more than 90 percent. However, if a country receives the same level of aid as Zambia did during the shock, the risk of conflict is reduced significantly, approximately to 12 percent.

55. Fundanga 2009, 11. 
test of a thousand people led by parliamentary representative Chishimba Kambwili. ${ }^{56}$ Despite the small number of formal layoffs-1,720 miners were let go-the total impact was far more widespread. Kambwili estimated that the mine supported 90 percent of the 180,000 residents in the area and indicated in the Washington Post that he believed the frustration would soon explode: "There's always a limit for people to be patient ... they will have to fight for what belongs to them." 57

Ultimately, Zambia weathered this shock quite peacefully. The evidence shows that foreign aid played a central role in mitigating the deleterious effects of the copper crisis. Foreign aid has long been a major source of external revenue for the Zambian economy, often exceeding both foreign direct investment (FDI) and remittances. Aid was used primarily to provide budget support for health, education, and poverty-reduction programs. In total, the Zambian government's budget depends on aid for 60 percent of its revenue. ${ }^{58}$ As a revenue stream, aid has remained stable despite the global recession. The stability of this revenue stream helped to ensure that "social protection interventions in health and education [were] safe," as aid was reallocated internally from specific projects to general budget support. ${ }^{59}$ Aid has been used to mitigate the shock as "social protection programmes are targeted at groups exposed to risks and shocks." 60 Thus, aid allowed for the continued support of programs that were critical for avoiding "social upheaval," enabling the Zambian government to peacefully weather the shock.

Having outlined the primary mechanism through which aid can decrease the risk of conflict in times of economic downturn, there are a number of additional points that merit consideration. The first of these is the question of aid fungibility. Inherent in our argument is an understanding that governments enjoy some degree of flexibility in their ability to reallocate aid toward particular types of expenditures even if this is not explicitly permitted under the terms of the grant. Supportive of this is existing evidence that foreign aid is largely fungible. ${ }^{61}$ To the extent that aid is fungible, it can reduce the constraints on a government's ability to maintain its precrisis spending levels. Even if aid is not fully fungible, aid revenues targeted at particular types of government programs may free up resources that governments may have already allocated for these expenses, thereby allowing these resources to be redirected to other needs. ${ }^{62}$

Our argument regarding the relationship between foreign aid and civil conflict is also explicitly a short-term phenomenon. We anticipate that aid's effect on the risk of conflict will be most pronounced in the period immediately following the

56. Karin Brulliard, "Zambia’s Copperbelt Reels From Global Crisis," Washington Post (Internet ed.), 25 March 2009.

57. Ibid.

58. Ndulo et al. 2009.

59. Ibid., 18.

60. Ibid., 32 .

61. See Pack and Pack 1990; Boone 1996; and Feyzioglu, Swaroop, and Zhu 1998.

62. Kosack and Tobin 2006. 
economic shock. We are agnostic about the long-term relationship between the two because our proposed mechanism is time-constrained; the aid effect should be observed only in the immediate aftermath of an economic shock. We hold this belief for a number of reasons.

First, some economic aid packages attach conditions targeted at reducing government spending, and, one might therefore expect to see a negative relationship between aid and government spending. ${ }^{63}$ However, the empirical validity of this expectation is contested and there is evidence that aid contributes to increases in government spending. ${ }^{64}$ Second, and more importantly, our argument does not require that a government actually increase spending in response to an economic shock for our proposed effect to hold. If the aid can simply reduce the amount of spending cuts the government is forced to undertake, it can dampen the procyclical pressures and thereby reduce the likelihood of a conflict onset.

Finally, within the larger literature on aid and conflict, the long-run equilibrium is unclear. This is true for a number of reasons. The first is that aid could have a long-run effect on peace if aid were effective in stimulating recipient economic development, since high levels of economic development are associated with a lower risk of conflict. However, there is no consensus in the literature that aid always stimulates development, and thus aid's ability to reduce the likelihood of conflict through growth is similarly opaque. On the other hand, aid may contribute to conflict in the long run by increasing cronyism and corruption in the recipient country. ${ }^{65}$

Given these potentially competing ways in which aid may affect the risk of conflict, the long-run relationship between aid and conflict is not a priori clear. In some ways, this is related to the final issue we wish to address, that of government preferences. Since aid operates through the government, the preferences of the government on spending may be of concern. ${ }^{66}$ We agree that governments do not have a monolithic preference regarding types of spending. Our argument, however, is not conditional on a particular type of government spending. Drawing on the selectorate theory of Bueno de Mesquita and others, we assume that leaders are rational and want first and foremost to stay in power. ${ }^{67}$ To do so, they choose a distribution of spending across various areas that best allows them to maintain office in the long run. Some governments may prefer large defense budgets, others large budgets for welfare expenses, while others may provide a small winning coalition with private goods, depending on various domestic and international con-

63. To deal with this possibility, we include a measure of participation of the recipient country in an IMF program in our empirical tests.

64. See Feyzioglu, Swaroop, and Zhu 1998; Morrison 2009; Pack and Pack 1990; Remmer 2004; and Feeny 2007. In his analysis of the fiscal effects of aid in Ethiopia between 1964 and 2005, Martins 2007 shows that in addition to directly financing new government spending, especially capital expenditures, aid has an indirect effect on public expenditures by substituting for domestic borrowing.

65. Bueno de Mesquita and Smith 2009.

66. Kosack and Tobin 2006.

67. Bueno de Mesquita et al. 2003. 
siderations. ${ }^{68}$ However, at times of severe economic crises when the risk of civil war is particularly high, rational leaders are likely to spend economic resources at their disposal, such as foreign aid, in ways that avert attacks on the regime and ensure their political survival, no matter what their spending preferences may be in stable times. ${ }^{69}$

Mindful of the considerations outlined above, we propose the following hypothesis:

H1: The higher the amount of foreign aid a country receives, the lower is its risk of experiencing a civil war following an economic shock.

\section{Research Design}

We test our hypothesis on a sample of ODA or Official Assistance (OA) eligible countries for the fifteen-year period of 1990 to $2004 .^{70}$ The unit of analysis is the country-year. The dependent variable is CONFLICT ONSET, which is coded 1 for the first year of a conflict and 0 otherwise. We use the Uppsala/PRIO Conflict Data Set to identify civil wars involving at least 1,000 battle deaths over the course of a conflict. ${ }^{71}$

Our argument focuses on two primary independent variables: foreign aid and negative economic shocks. For foreign aid, we create TOTAL AID, which is a measure of ODA and OA from the OECD. We measure TOTAL AID in constant 2005 United States dollars per 1,000 citizens in the recipient country. ${ }^{72}$

To measure economic shocks we focus on shocks in global agricultural raw materials prices. ${ }^{73}$ We use agricultural raw materials for two reasons. First, many de-

68. Similarly, one might argue that aid-spending patterns across different regime types can be heterogeneous. For instance, the way democratic and autocratic leaders spend aid to fend off domestic conflict may differ. However, for the purposes of our argument it is only necessary that political leaders act with the purpose of avoiding conflict and are assisted in doing so by having aid monies available. Due to data limitations and theoretical constraints, we do not test the effect of domestic spending patterns by various regime types. Splitting our sample by regime type yields results consistent with our argument.

69. Bueno de Mesquita and Smith 2010 adopt a similar assumption and show that leaders will use resources such as aid to try to rebuff challenges to their office, such as antigovernment demonstrations or riots.

70. The inclusion of aid-eligible countries who are not aid recipients in a particular year mitigates concerns of selection induced by limiting the sample to actual recipients. Countries that are aid-eligible, but for which no aid data are recorded in a given year, are coded as receiving no aid in that year.

71. See Eriksson, Wallensteen, and Sollenberg 2003; and Gleditsch et al. 2002. For robustness check, we reestimated our models using minor conflicts (25-999 battle deaths) as the dependent variable. The main results remain the same.

72. Since our mechanism depends on changes in GDP, dividing aid by GDP would conflate an exogenous economic shock with our aid measure by producing a single variable reflecting both factors.

73. Although we utilize a measure of exports to represent economic shocks, our theory does not require that the shock be derived from a country's export sector. Any economic downturn should generate similar dynamics, so shocks derived from other sources, such as an unanticipated outflow of foreign portfolio investment, should have a similar effect, assuming that the shock negatively affects government revenues. 
veloping countries are reliant on agricultural exports. Second, the use of resources that are themselves related to conflict, such as oil and diamonds, could potentially conflate these effects with the effect of an economic shock. We construct an AGRICULTURAL SHOCK measure using an index of global agricultural raw material prices from the commodity price data from the International Monetary Fund (IMF) ${ }^{74}$ We classify years for which the decreases in agricultural index prices from the previous year are in the bottom 10 percentile of the observed distribution as having experienced an "agricultural shock." 75 There are two significant benefits to our operationalization. First, a dichotomous shock variable ensures that we account for the effect of pronounced income changes rather than treating changes in index prices as a continuum with constant marginal effects. Second, the use of a global index of general agricultural commodities rather than a single commodity helps reduce concerns of endogeneity. Using an aggregated measure means that shocks are more likely to be the result of systemic factors, rather than changes in a single commodity price. With an index measure, we can assume that countries are pricetakers rather than price-setters-which may not be the case using country-specific changes or particular commodities (such as coffee). ${ }^{76}$

Simply using the change in the commodity price index may not accurately represent the effect of an economic shock within our hypothesized mechanism, however. This is the case for two reasons. First, it is important to differentiate between countries that benefit from or are hurt by the change in prices as changes in the agricultural index prices affect producer and consumer states differently. Additionally, even though developing countries are generally more reliant on agricultural exports than developed countries, there is substantial heterogeneity among developing countries in their level of agricultural exports. To account for these dynamics, we interact the agricultural shock variable with an indicator of a country's vulnerability to such shocks, AGRICULTURAL EXPORTS. The AGRICULTURAL EXPORTS variable measures a country's value of agricultural exports as a percentage of its GDP. ${ }^{77}$

74. The data, available at $\langle$ http://www.imf.org/external/np/res/commod/index.asp $\rangle$, accessed 25 April 2012, are in monthly format, so to construct an annual measure we took the average for the calendar year of the twelve monthly observations. The index uses 2005 as a base year, where 2005 $=100$. The World Bank agricultural raw materials exports measure covers goods within category 2 of the Standard International Trade Classification (SITC). Examples include crude rubber, cork, wood, and crude animal and vegetable materials.

75. This measure is similar to the measure of economic shocks utilized by Collier and Goderis 2009b, who also use the lower tenth percentile of a commodity index (though in a different form) to represent negative price shocks.

76. We ran additional models with a "country-specific" measure of shock to ensure that our results are not merely an artifact of the way we constructed our shock term. The new measure uses countryspecific terms of trade shocks and merchandise exports. The results of this alternative shock measure are consistent with the findings of our original shock measure.

77. Since the value of the agricultural exports is compared to the size of the overall economy, scaling the measure as a percentage of GDP yields low values for AGRICULTURAL SHOCK (0-21). These small values do not necessarily capture the full contribution of agriculture to the country's economy but merely represent the relative value of agricultural exports to the overall economy. Any agricultural production that is consumed domestically is not reflected in our measure, so countries that are highly 
The higher the value of AGRICULTURAL EXPORTS, the more vulnerable a country is to agricultural shocks, which translates into greater economic dislocation as a function of changes in agricultural prices. ${ }^{78}$ In order to avoid reflecting the effect of the shock itself in the measure of exports, we lag AGRICULTURAL EXPORTS one period prior to both AGRICULTURAL SHOCK and TOTAL AID. ${ }^{79}$ The data for AGRICULTURAL EXPORTS come from the World Bank's World Development Indicators.

To account for the hypothesized conditional relationship between aid and economic shocks, we create a series of interaction terms utilizing TOTAL AID, AGRICUlTURAL SHOCK, and AGRICUlTURAL EXPORTS. The interactions include three double interactions, in which each of the variables are individually interacted with the other two, and a triple interaction involving all three terms.

In addition to the primary independent variables outlined here, we also include a series of country-specific control variables in our models. The first of these controls is the level of DEMOCRACY measured using the Polity IV scale ranging from -10 to +10 , where -10 represents perfect autocracy and +10 perfect democracy. ${ }^{80}$ REAL PER CAPITA GDP measures the level of economic development as real GDP per capita in constant 2000 international dollars; GDP GROWTH is the annual percent change in GDP; and POPULATION is the natural log of population in thousands of individuals. Data for both REAL PER CAPITA GDP and POPULATION come from the Penn World Tables, ${ }^{81}$ while GDP GROWTH is taken from the World Bank's World Development Indicators. Table 1 provides a series of descriptive statistics of the variables utilized in the empirical analysis.

Given the binary nature of the dependent variable, we utilize a probit estimator with robust standard errors clustered by country. The use of a binary dependent variable with time-series cross-sectional data also necessitates consideration of the data's temporal dynamics. ${ }^{82}$ We therefore add a time counter, PEACE YEARS, which measures the number of years since the previous 1,000 battle deaths conflict initiation. Additionally, we utilize the cubic-spline approach advocated by Beck and colleagues, which creates three splines to account for potential nonlinear effects

dependent on agricultural production but consume most of the goods they produce may have low values on our scale.

78. An alternative to our specification would be to utilize changes in GDP as a measure of economic shocks. However, because government spending is a component of GDP, there is an endogeneity issue when using general economic figures. By isolating a source of economic change in the form of agricultural prices, we can isolate the cause and response mechanisms in the form of price index changes and government spending changes. This is again similar to the approach of Collier and Goderis 2009b who weight their shock variable by the exports share of overall GDP.

79. We utilize the sector-specific degree of openness to most closely measure how susceptible the country is to the changing index prices. Specifying the relationship with the external source of the shock is important in light of Kim's 2007 finding that it is not openness per se that increases domestic volatility, but the external sources of volatility.

80. Marshall and Jaggers 2002.

81. Heston, Summers, and Aten 2006.

82. Beck, Katz, and Tucker 1998. 
of time. ${ }^{83}$ We also use the alternative approach suggested by Carter and Signorino, which includes year, year squared, and year cubed to allow for a potential nonlinear relationship between time and the dependent variable. ${ }^{84}$

TABLE 1. Descriptive statistics

\begin{tabular}{lcrrrr}
\hline & $\begin{array}{c}\text { Number of } \\
\text { observations }\end{array}$ & Mean & $\begin{array}{c}\text { Standard } \\
\text { deviation }\end{array}$ & Minimum & Maximum \\
\hline TOTAL AID & 2,384 & 86.5 & 419.76 & $-233.2^{1}$ & 14975.68 \\
AGRICULTURAL SHOCK & 2,883 & 0.14 & 0.34 & 0 & 1 \\
AGRICULTURAL EXPORTS & 1,544 & 1.28 & 2.51 & 0 & 21.25 \\
DEMOCRACY & 1,972 & 1.40 & 6.66 & -10 & 10 \\
REAL PER CAPITA GDP & 2,194 & 6078.48 & 6434.53 & 170.56 & 36504.74 \\
GDP GROWTH & 2,276 & 3.22 & 7.28 & -51.03 & 106.28 \\
POPULATION (logged) & 2,384 & 8.48 & 2.04 & 2.81 & 14.07 \\
PEACE DURATION & 2,165 & 6.46 & 4.28 & 0 & 14 \\
\hline
\end{tabular}

1. It is possible for aid to have negative values in cases where repayments on loans exceed current distributions or where governments seek to recover monies from prior grants (e-mail communication from A. Zimmerman of OECD's Development Assistance Committee, 22 February 2007).

The probit model takes the following form: ${ }^{85}$

$$
\begin{aligned}
& \operatorname{CONFLICT~ONSET~}_{i t}=\Phi\left(\alpha+\beta_{1} * \text { TOTAL AID }_{i t-1}+\beta_{2} * \text { AGRICULTURAL SHOCK }_{t-1}\right.
\end{aligned}
$$

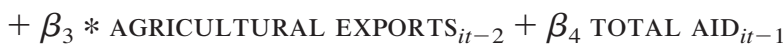

$$
\begin{aligned}
& \text { * AGRICUltural } \text { SHOCK }_{t-1}+\beta_{5} * \text { TOTAL AID }_{i t-1} \\
& \text { * AgRicultural EXPORTs }{ }_{i t-2}+\beta_{6} \\
& \text { * AGRICUltural } \text { SHOCK }_{t-1} \\
& \text { * AGRICULTURAL EXPORTs }{ }_{i t-2}+\beta_{7} * \text { TOTAL AID }_{i t-1} \\
& \text { * AGRICULTURAL } \text { SHOCK }_{t-1} \\
& \text { * AGRICULTURAL EXPORTS }{ }_{i t-2} \\
& \left.+\beta * \text { CONTROLS }_{i t-2}+\beta * \text { PEACE YEARS }_{i t}\right)
\end{aligned}
$$

H1 posits that foreign aid should reduce the likelihood of a conflict onset in the presence of an economic shock. We expect this effect to be particularly high for

83. Ibid.

84. Carter and Signorino 2010.

85. $\Phi$ represents the cumulative distribution function. 
countries with a higher percentage of agricultural exports. Based on our model, the empirical result that would support this hypothesis would be as follows: ${ }^{86}$

$$
\frac{\partial \Phi(\cdot)}{\partial \mathrm{TOTAL} \text { AID }}=\left(\begin{array}{l}
\beta_{1}+\beta_{4} * \text { AGRICULTURAL SHOCK }+\beta_{5} \\
* \text { AGRICULTURAL EXPORTS }+\beta_{7} \\
* \text { AGRICULTURAL SHOCK } \\
* \text { AGRICULTURAL EXPORTS }
\end{array}\right) \Phi^{\prime}(\cdot)<0
$$

A result in line with the above equation would indicate that the marginal effect of a one-unit increase in TOTAL AID would decrease the likelihood of CONFLICT ONSET, conditional on the level of agricultural exports.

\section{Empirical Findings and Discussion}

We begin our analysis using a basic specification estimating the effect of TOTAL AID, AGRICUltURAL SHOCK, AGRICULTURAL EXPORTS, and the series of interactions on civil conflict initiation. These results are presented in model 1 in Table 2.

The complex nature of equation (2) means that the statistical significance of the proposed effects has to be evaluated using the appropriate corrected standard error and that the t-statistics of the individual terms are of limited usefulness. ${ }^{87}$ Because one of the most effective ways to analyze both the size of the effect and its statistical significance is graphically, we provide a number of graphical analyses in conjunction with the tables to evaluate the effect of aid on conflict. ${ }^{88}$

Figure 1 presents the marginal effects of foreign aid on civil war onset conditional on the presence of an economic shock and a country's sensitivity to it. ${ }^{89}$ The upper part of the figure shows that aid has a conflict-suppressing effect in the wake of an economic shock, which increases as a country's level of exports increases. The lower part graphs the effect of an economic shock upon conflict in the affected country without foreign aid. In line with our expectation, we find that

86. Equations (1) and (2) are based on Brambor, Clark, and Golder 2006, 77.

87. Ibid., 70.

88. The graphs are generated using the code for double interactions with a binary dependent variable developed by Matt Golder. Available at 〈https://files.nyu.edu/mrg217/public/interaction. html\#code $\rangle$. Accessed 25 April 2012. We updated this code to allow for application to triple interaction models. The figures utilize 10,000 replications of the estimator at various levels of the conditioning variable to predict the probability of a conflict onset. The differences between the 0 and 1 values are used as the marginal effect and a 95 percent confidence interval is also constructed, allowing for point estimations and statistical significance testing. The graphs are also computed up to 6 percent agricultural exports, which is approximately the ninety-fifth percentile of the sample, to avoid compression of the graph range associated with extreme values.

89. The models are estimated using all controls set to their respective lagged means. 
economic shocks increase the likelihood of conflict initiation in countries where no aid is received (figure 1 bottom).

The results in Model 1 hold when we add controls for the economic development, growth, regime type, and population of a country and the years since the last civil war (model 2). To address temporal dependence, model 3 utilizes the cubic splines, while model 4 uses cubic polynomial approximation..$^{90}$ The results are consistent for these two common ways of modeling temporal dependence.

TABLE 2. One thousand battle death onset

\begin{tabular}{|c|c|c|c|c|}
\hline & $\begin{array}{c}\text { (1) } \\
\text { Model } \\
\text { without } \\
\text { controls }\end{array}$ & $\begin{array}{l}\text { (2) } \\
\text { Base } \\
\text { model }\end{array}$ & $\begin{array}{c}\text { (3) } \\
\text { Cubic } \\
\text { splines }\end{array}$ & $\begin{array}{c}\text { (4) } \\
\text { Carter- } \\
\text { Signorino }\end{array}$ \\
\hline TOTAL AID & $\begin{array}{c}-0.009 * * \\
(0.004)\end{array}$ & $\begin{array}{c}-0.022^{*} \\
(0.013)\end{array}$ & $\begin{array}{c}-0.029 * * \\
(0.014)\end{array}$ & $\begin{array}{c}-0.027 * * \\
(0.013)\end{array}$ \\
\hline AGRICULTURAL SHOCK & $\begin{array}{c}0.221 \\
(0.443)\end{array}$ & $\begin{array}{r}-0.200 \\
(0.440)\end{array}$ & $\begin{array}{c}0.164 \\
(0.788)\end{array}$ & $\begin{array}{c}0.502 \\
(0.881)\end{array}$ \\
\hline AGRICULTURAL EXPORTS & $\begin{array}{r}-0.578 \\
(0.368)\end{array}$ & $\begin{array}{c}-0.962^{*} \\
(0.505)\end{array}$ & $\begin{array}{c}-1.260 * * \\
(0.529)\end{array}$ & $\begin{array}{c}-1.200 * * \\
(0.496)\end{array}$ \\
\hline $\begin{array}{l}\text { AGRICULTURAL SHOCK } \\
* \text { AGRICULTURAL EXPORTS }\end{array}$ & $\begin{array}{l}0.817 * * \\
(0.350)\end{array}$ & $\begin{array}{l}1.440 * * \\
(0.558)\end{array}$ & $\begin{array}{l}2.030 * * * \\
(0.538)\end{array}$ & $\begin{array}{l}1.680 * * * \\
(0.551)\end{array}$ \\
\hline TOTAL AID $*$ AGRICULTURAL SHOCK & $\begin{array}{c}-0.022 * * \\
(0.009)\end{array}$ & $\begin{array}{c}-0.035^{*} \\
(0.021)\end{array}$ & $\begin{array}{c}-0.035 \\
(0.038)\end{array}$ & $\begin{array}{c}-0.080 * * \\
(0.039)\end{array}$ \\
\hline TOTAL AID $*$ AGRICULTURAL EXPORTS & $\begin{array}{c}0.007^{*} \\
(0.004)\end{array}$ & $\begin{array}{l}0.012 * * \\
(0.005)\end{array}$ & $\begin{array}{l}0.015^{* * * *} \\
(0.005)\end{array}$ & $\begin{array}{l}0.014 * * * \\
(0.005)\end{array}$ \\
\hline $\begin{array}{l}\text { TOTAL AID * AGRICULTURAL SHOCK } \\
* \text { AGRICULTURAL EXPORTS }\end{array}$ & $\begin{array}{l}-0.020 * * \\
(0.008)\end{array}$ & $\begin{array}{l}-0.042 * * * \\
(0.016)\end{array}$ & $\begin{array}{l}-0.074 * * * \\
(0.027)\end{array}$ & $\begin{array}{c}-0.044^{*} \\
(0.025)\end{array}$ \\
\hline DEMOCRACY & & $\begin{array}{c}-0.055^{* *} \\
(0.027)\end{array}$ & $\begin{array}{l}-0.083^{* * *} * \\
(0.027)\end{array}$ & $\begin{array}{c}-0.079 * * * \\
(0.028)\end{array}$ \\
\hline REAL PER CAPITA GDP & & $\begin{array}{c}-0.0001 * * \\
(0.00006)\end{array}$ & $\begin{array}{c}-0.0002 * * * \\
(0.00006)\end{array}$ & $\begin{array}{c}-0.0002 * * * \\
(0.00005)\end{array}$ \\
\hline GDP GROWTH & & $\begin{array}{l}0.076 * * \\
(0.038)\end{array}$ & $\begin{array}{c}0.064 \\
(0.045)\end{array}$ & $\begin{array}{c}0.073 * \\
(0.038)\end{array}$ \\
\hline POPULATION $($ logged $)$ & & $\begin{array}{r}-0.027 \\
(0.163)\end{array}$ & $\begin{array}{r}-0.080 \\
(0.180)\end{array}$ & $\begin{array}{r}-0.073 \\
(0.161)\end{array}$ \\
\hline PEACE DURATION & & $\begin{array}{l}-0.145^{* * *} \\
(0.049)\end{array}$ & $\begin{array}{l}-0.360 * * * \\
(0.123)\end{array}$ & $\begin{array}{l}-1.640 * * * \\
(0.362)\end{array}$ \\
\hline Constant & $\begin{array}{l}-2.34 * * * \\
(0.22)\end{array}$ & $\begin{array}{c}-0.595 \\
(2.17)\end{array}$ & $\begin{array}{l}0.196 \\
(2.45)\end{array}$ & $\begin{array}{c}0.784 \\
(2.16)\end{array}$ \\
\hline Observations & 1,273 & 1,132 & 1,132 & 1,132 \\
\hline Number of clusters & 130 & 117 & 117 & 117 \\
\hline Akaike information criterion & 70.58 & 64.64 & 63.22 & 64.82 \\
\hline
\end{tabular}

Notes: Robust standard errors clustered by country in parentheses. $* * * p<.01 ; * * p<.50 ; * p<.10$.

Figure 2 illustrates the effect of aid on conflict initiation using the more fully specified model 2. The figure shows that in the absence of an agricultural shock, aid has no statistically significant effect upon CONFLICT ONSET because the 95

90. See Beck, Katz, and Tucker 1998; and Carter and Signorino 2010. 
Marginal effect of total aid on conflict initiation (conditional on agricultural exports and agricultural shock)

Shock present

$\$ 1$ increase in aid

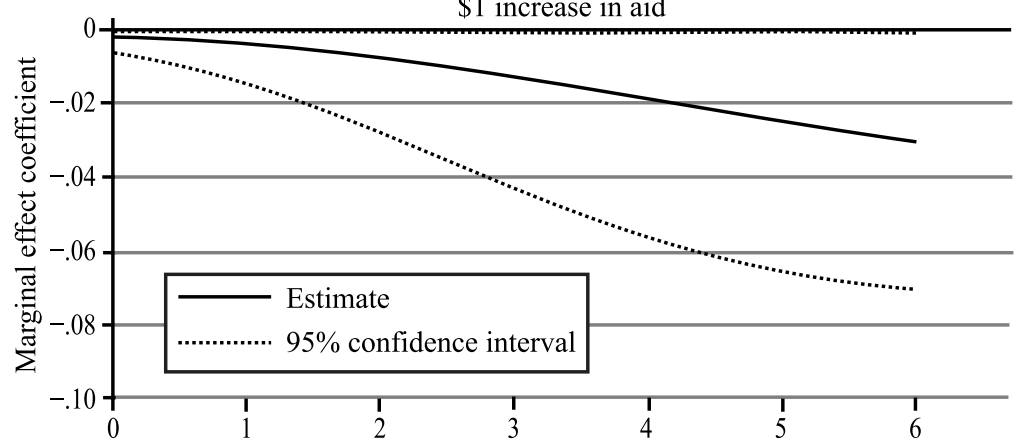

Agricultural exports as percentage of GDP

Marginal effect of an agricultural shock on conflict initiation

(conditional on agricultural exports and total aid)

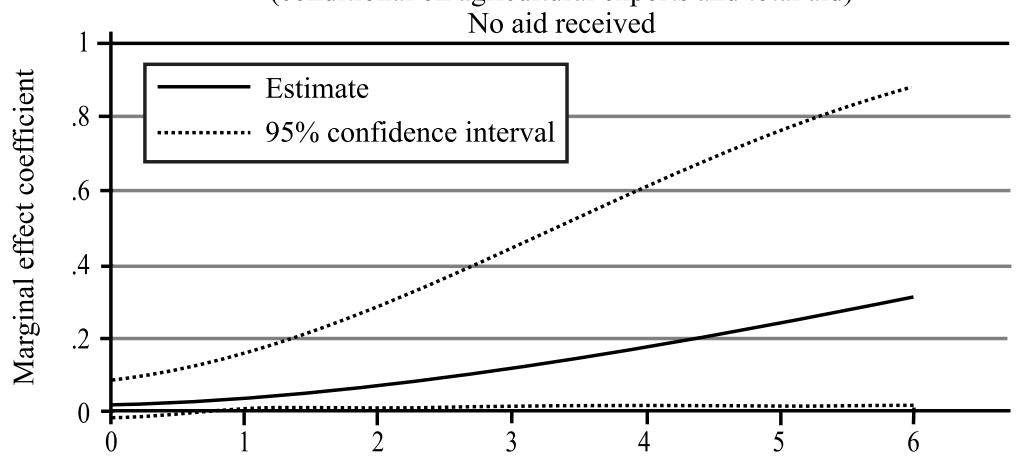

Agricultural exports as percentage of GDP

FIGURE 1. Model estimates without control

percent confidence interval lies firmly around zero (figure 2A). However, in the presence of an economic shock, the estimated effect of aid is entirely below zero, in linewith H1 (Figure 2B). ${ }^{91}$ For example, when AgRICUltural EXPORTS are approximately 2 percent of GDP of a country, the marginal effect of TOTAL AID is

91. To ensure that the observed outcome is not a function of the complexity of the shock measure, we also run the estimation using an interaction between TOTAL AID and AGRICULTURAL SHOCK only rather than the triple interaction and associated double interactions. The results are similar to those of model 2: aid reduces the likelihood of a civil war onset in the presence of an agricultural shock. 

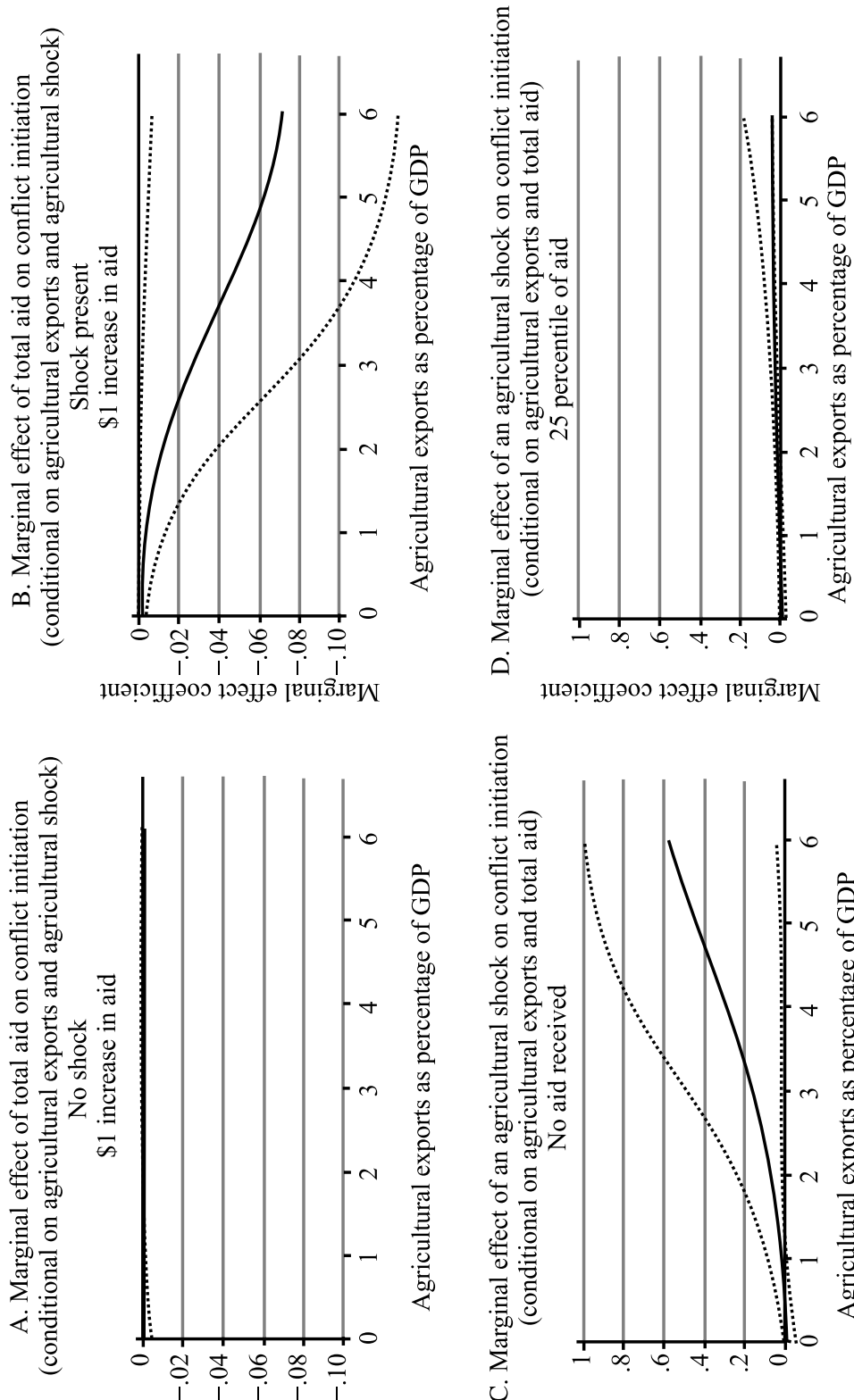

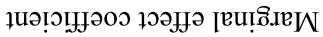

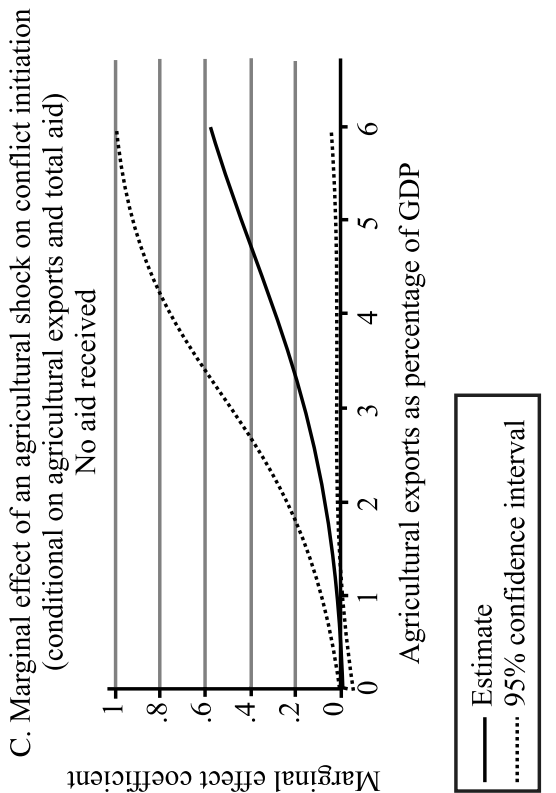


around -0.01 . This suggests that in the presence of an economic shock, a one-unit increase in TOTAL AID (or a $\$ 1$ increase in aid per 1,000 citizens) reduces the likelihood of a conflict onset by approximately 1 percent. When the level of agricultural exports increases to 4 percent of GDP, which is a relatively large figure for the reasons we discussed earlier, a $\$ 1$ increase in aid per 1,000 citizens reduces the likelihood of conflict by approximately 5 percent, holding everything else constant.

We also find that agricultural shocks increase the likelihood of conflict. ${ }^{92}$ Looking at agricultural shocks in the absence of aid, we see that shocks do in fact increase the likelihood of conflict, dependent on the level of agricultural exports (Figure 2C). ${ }^{93}$ When agricultural exports are low, shocks have no effect on conflict initiation. As a country's sensitivity to shock increases, shocks have a positive effect on the risk of conflict, ceteris paribus. When agricultural exports reach 6 percent of GDP, an agricultural shock increases the likelihood of an onset by approximately 60 percent.

Since aid serves as a conditioning variable for agricultural shock, just as the shock itself conditions the aid, it is important to examine aid's effect upon conflict initiation through the economic shock channel in addition to its direct effect. ${ }^{94}$ That is, aid's effect upon conflict initiation may also include its effect upon economic shocks. If aid reduces the likelihood of conflict initiation precipitated by an economic shock, this increases the magnitude of aid's effect. We plot the marginal effect of an economic shock upon conflict initiation when the recipient country receives aid equal to the twenty-fifth percentile of the sample. Figure 2D shows that aid attenuates the effect of an economic shock upon conflict. This is completely in line with our hypothesis: increasing aid can mitigate the likelihood that a conflict occurs as a function of an economic shock, not only through aid's direct effect but also by its ability to reduce the pernicious effects of a shock itself.

Among the control variables, higher levels of democracy and economic development, as well as each additional year a country is removed from the previous onset, reduce the likelihood of a conflict onset. Conversely, economic growth increases conflict likelihood. Population fails to have any statistically discernable effect on conflict initiation..$^{95}$

We subject the main findings from model 2 to a number of robustness tests to evaluate the stability of the results under a number of different constraints. The

92. We assess whether our results are sensitive to varying cut points for the AGRICULTURAL SHOCK measure; specifically, whether the results in model 2 are robust if shocks are measured at the fifth and fifteenth percentiles of changes in agricultural index price changes. The results are unchanged moving to the more restrictive fifth percentile measure, while the results do not hold using a more generous fifteenth percentile figure. We interpret this as indicative that our proposed effect is applicable when the shocks are sufficiently severe and more moderate shocks do not necessitate a similar type of government aid-assisted intervention.

93. This effect is equivalent to substituting AGRICULTURAL SHOCK for TOTAL AID in equation (2) and using the corrected standard error.

94. Berry, Golder, and Milton 2009.

95. For similar results, see Goldstone et al. 2010. 
first of these tests assesses the magnitude and statistical significance of the estimated effects of aid at various levels of initial aid allocations. Since the estimation results are dependent on the specification of both the level and magnitude of the change in aid, testing the effect varying both of these dynamics demonstrates whether the effect is significant across the full range of aid allocations. The results of this exercise are presented in Figure 3.

Figure $3 \mathrm{~A}$ shows a 10 percent increase in aid at the tenth percentile of aid levels (based on the sample distribution), and 3B shows the equivalent change at the twenty-fifth percentile. We see that aid decreases the likelihood of civil war onset in both cases. ${ }^{96}$ We also estimate the effect of a 10 percent increase in aid on conflict at increasing levels of aid allocation. Aid still decreases the risk of conflict although its effect diminishes as initial aid levels go up. This suggests that increases at low initial aid allocations have a stronger dampening effect upon conflict than increases at higher allocation levels.

It is possible that the affected country's participation in an IMF program may influence our proposed mechanism, in line with the earlier discussion of aid conditionality. To address this concern, we run model 2 using a dummy variable, IMF PROGRAM, which assumes a value of " 1 " if the country is currently participating in an IMF program. ${ }^{97}$ The results of this estimation are presented in model 5.

Encouragingly, the inclusion of the IMF variable does not change our original results. The marginal effect of aid is once again negative and statistically significant (Figure 3C). Figure 3D shows the marginal effect of an economic shock when the country receives aid equivalent to the twenty-fifth percentile of the sample and is participating in an IMF program. The effect of a shock is similar to one depicted by Figure 2D. These results suggest that the presence or absence of an IMF program is not a confounding factor for our proposed mechanism. Furthermore, the fact that the IMF variable is positive and significant provides further evidence for our general mechanism since extant literature provides a significant amount of evidence that the main effect of IMF programs is to force governments to reduce spending. ${ }^{98}$

While it is possible that donors may adjust their aid allocations based on conflict initiations in recipient countries, ${ }^{99}$ for a number of reasons, we believe that

96. Graphically the upper $95 \%$ confidence intervals in some of the figures appear close to zero. In these cases statistical significance was determined using the specific estimated value for the confidence interval.

97. The data for this variable come from Vreeland 2007. The IMF data are available through 2000 only.

98. See Vreeland 2003; and Nooruddin and Simmons 2006.

99. We also guard against the possibility that the level of aid a country receives may be influenced by its domestic political institutions. If donors prefer to allocate aid to countries with high governance quality, the estimated effect of aid on conflict may be biased since good governance should also result in less conflict, ceteris paribus. For example, Fearon 2010 shows that high quality of governance in a country, such as high bureaucratic quality and democratic accountability and low corruption, reduces the risk of civil wars. If countries with good political institutions also receive greater amounts of foreign aid, then our results may be biased; that is, we may be overestimating the conflict-suppressing effects 


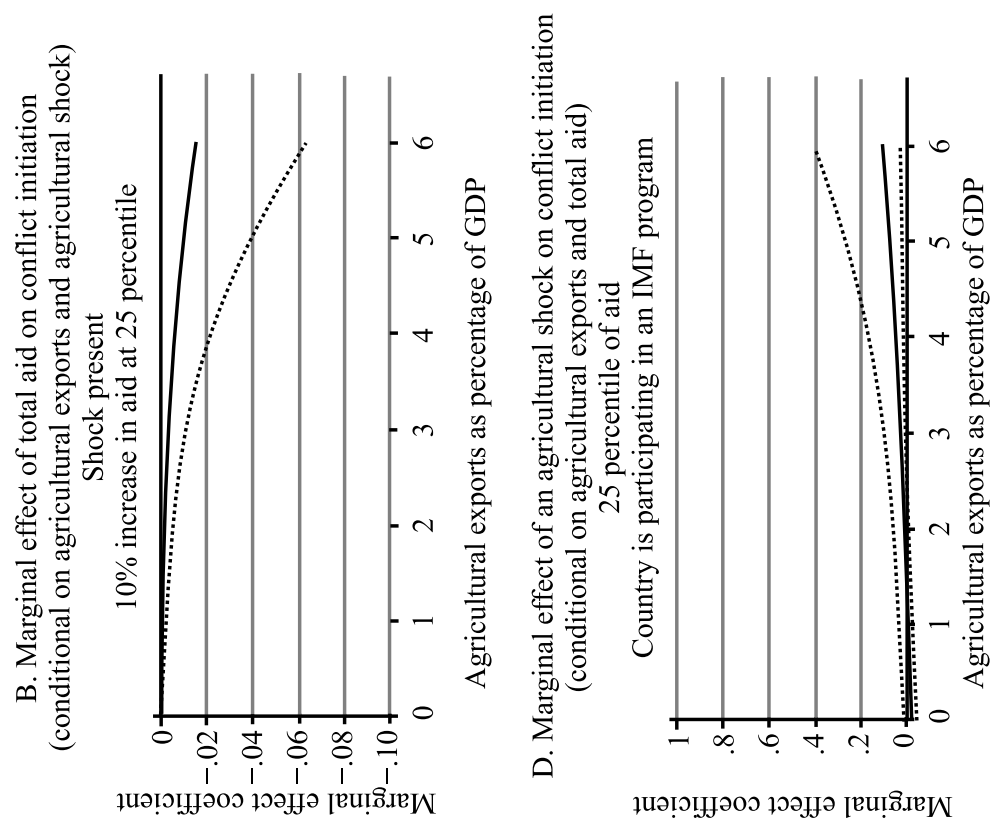

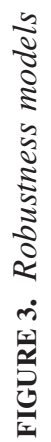
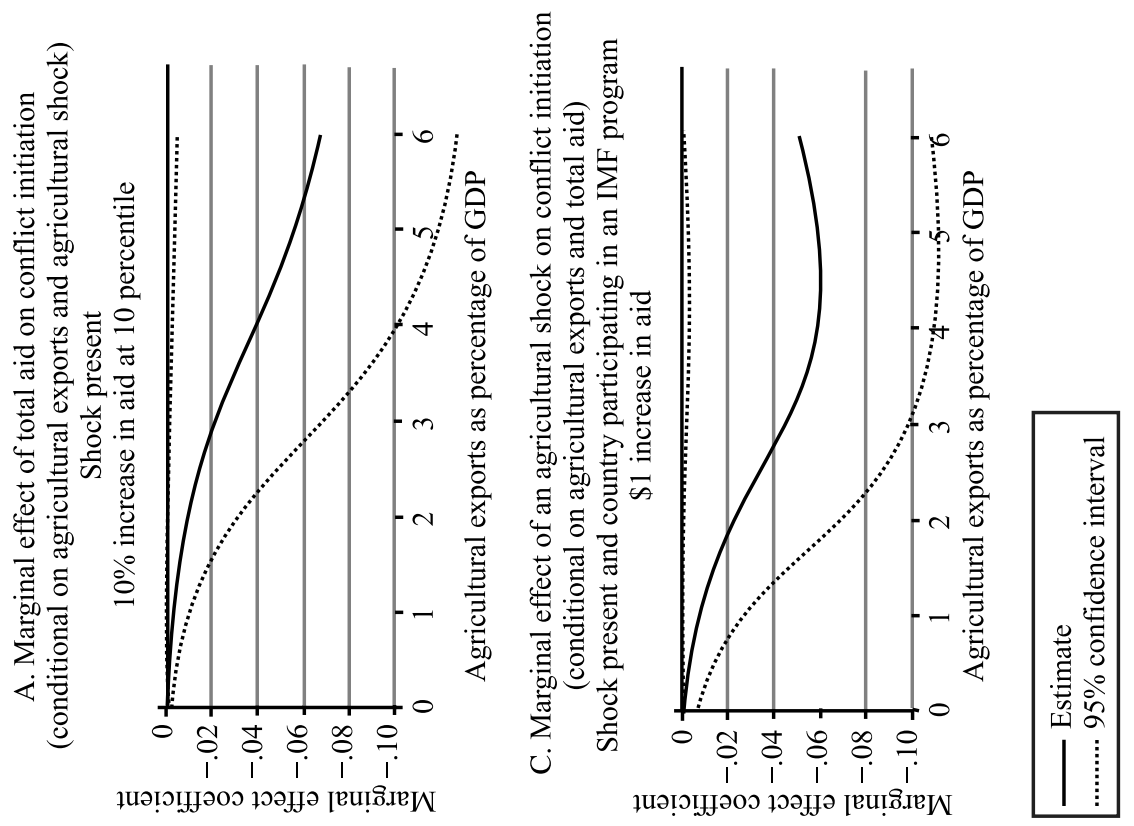
TABLE 3. Robustness tests

\begin{tabular}{|c|c|c|}
\hline & $\begin{array}{c}(5) \\
I M F \text { program }\end{array}$ & $\begin{array}{l}\text { (6) } \\
\text { Alternative } \\
\text { aid lag }\end{array}$ \\
\hline TOTAL AID & $\begin{array}{c}-0.024^{*} \\
(0.014)\end{array}$ & $\begin{array}{c}-0.130^{*} \\
(0.008)\end{array}$ \\
\hline AGRICULTURAL SHOCK & $\begin{array}{r}-0.246 \\
(0.422)\end{array}$ & $\begin{array}{c}-0.243 \\
(0.400)\end{array}$ \\
\hline AGRICULTURAL EXPORTS & $\begin{array}{c}-0.949^{*} \\
(0.503)\end{array}$ & $\begin{array}{r}-0.090 \\
(0.110)\end{array}$ \\
\hline AGRICULTURAL SHOCK * AGRICULTURAL EXPORTS & $\begin{array}{l}1.540 * * \\
(0.608)\end{array}$ & $\begin{array}{l}1.120 \text { *** } \\
(0.290)\end{array}$ \\
\hline TOTAL AID * AGRICULTURAL SHOCK & $\begin{array}{c}-0.040 \\
(0.026)\end{array}$ & $\begin{array}{c}0.007 \\
(0.010)\end{array}$ \\
\hline TOTAL AID * AGRICULTURAL EXPORTS & $\begin{array}{l}0.012 * * \\
(0.005)\end{array}$ & $\begin{array}{c}0.0017 \\
(0.0013)\end{array}$ \\
\hline TOTAL AID*AGRICULTURAL SHOCK*AGRICULTURAL EXPORTS & $\begin{array}{c}-0.044 * * \\
(0.021)\end{array}$ & $\begin{array}{c}-0.107 * * * \\
(0.030)\end{array}$ \\
\hline DEMOCRACY & $\begin{array}{c}-0.069 * * * \\
(0.025)\end{array}$ & $\begin{array}{c}-0.025 \\
(0.028)\end{array}$ \\
\hline REAL PER CAPITA GDP & $\begin{array}{c}-0.0001 * \\
(0.00007)\end{array}$ & $\begin{array}{r}-0.0001 * * \\
(0.00005)\end{array}$ \\
\hline GDP GROWTH & $\begin{array}{l}0.090 * * \\
(0.039)\end{array}$ & $\begin{array}{l}0.060 * * * \\
(0.020)\end{array}$ \\
\hline POPULATION (logged) & $\begin{array}{c}0.040 \\
(0.160)\end{array}$ & $\begin{array}{r}-0.070 \\
(0.140)\end{array}$ \\
\hline PEACE DURATION & $\begin{array}{c}-0.113^{* *} \\
(0.058)\end{array}$ & $\begin{array}{c}-0.150 \text { *** } \\
(0.050)\end{array}$ \\
\hline IMF PROGRAM & $\begin{array}{l}0.808^{* * * *} \\
(0.250)\end{array}$ & \\
\hline Constant & $\begin{array}{r}-2.070 \\
(2.060)\end{array}$ & $\begin{array}{r}-0.383 \\
(1.790)\end{array}$ \\
\hline Observations & 811 & 1127 \\
\hline Number of clusters & 107 & 117 \\
\hline Akaike information criterion & 64.24 & 73.22 \\
\hline
\end{tabular}

Notes: Robust standard errors clustered by country in parentheses. $* * * p<.01 ; * * p<.50 ; * p<.10$.

endogeneity is not a particular concern for our results. First, in our models aid is lagged one period, reducing the likelihood that endogeneity is an issue, given that aid temporally precedes conflict. Second, as discussed, aid is largely unresponsive to economic shocks, reducing the possibility that aid could be codetermined with

of aid. To deflect such concerns, we ran a series of models of aid flows using four indicators of good governance from the International Country Risk Guide (ICRG): INVESTMENT PROFILE, CORRUPTION, LAW AND ORDER, DEMOCRATIC ACCOUNTABILITY, and BUREAUCRATIC QUALITY. Available at http:// www.prsgroup.com/ICRG.aspx 〉. Accessed 25 April 2012. The results show that none of the good governance variables is positively associated with the level of aid flows, indicating that aid is not given predominantly to countries with "good" institutions. For similar findings, see Neumayer 2003a, 2003b. 
shocks and civil war onset. Third, given the nature of economic shocks examined here, it would be difficult for the aid allocation decisions to be predicated on anticipated conflicts precipitated by economic shocks in the future. This is particularly true since countries are susceptible to different types of shocks.

To deflate any possible remaining concerns about endogeneity, we run an additional model where we increased the lag on the TOTAL AID term by an additional three years. If endogeneity were to be present in this specification, countries would need to condition their aid allocations on the perceived likelihood of a conflict onset four years from the date the aid was distributed, which is likely a year or more prior to the year the decision was made to allocate the aid. The results of the model using the four-year lag of TOTAL AID are presented in model 6 . We find that even in the presence of the increased lag, the effect of aid is still negative (conflictdecreasing) and significant.

We subject our results to three additional robustness tests not reported here due to space constraints. It is possible that there are some country-specific factors inducing omitted variable bias in our previous specifications. To account for these factors, we estimate a population-averaged probit regression. ${ }^{100}$ The findings are consistent with the results of model 2. The marginal effect of aid continues to be negative, statistically significant, and with a downward slope. To reduce the effect of possible outliers, we also estimate models restricting the samples to the ninetyfifth percentile (and below) for AGRICULTURAL EXPORTS and TOTAL AID. The results of the model with the restricted sample remain unchanged. Finally, we assess our hypothesis by dividing our sample by the domestic political institutions of the aid recipients. No substantive difference was observed across different regime types. Foreign aid insulates the budgets of all governments, regardless of regime type, from negative revenue shocks. ${ }^{101}$

What is the substantive effect of foreign aid on the probability of civil war onset? Figure 4 plots the predicted probability of a conflict induced by an economic shock at various levels of aid and agricultural exports.

As would be predicted by our hypothesis, countries receiving no aid and experiencing an agricultural shock have a large probability of experiencing a conflict onset (Figure 4A). This probability increases as the country's dependence on agricultural raw material exports increases (Figure 4B). As aid allocations go up, how-

100. We utilize the population-averaged probit estimator rather than a fixed-effects probit model because the latter is inconsistent in small- $\mathrm{T}$ and large-N samples, as ours is, due to the problem of incidental parameters. For a technical discussion of this issue see Wooldridge 2002, 484. Although there are some fixed-effects probit models that attempt to address this issue, we prefer to utilize the more straightforward population-averaged approach, which deals with the individual unit effects better by generating coefficients representing the effect for an "average" member of the sample. These models also have the additional benefit of being drawn directly from the sample population without having to make assumptions about individual member heterogeneity. Zeger, Liang, and Albert 1988, 1050-51.

101. The main results continue to hold when the models are estimated using the governance quality variables discussed in note 99. 
A. Predicted probability of a conflict onset during an agricultural shock (conditional on agricultural exports and total aid)

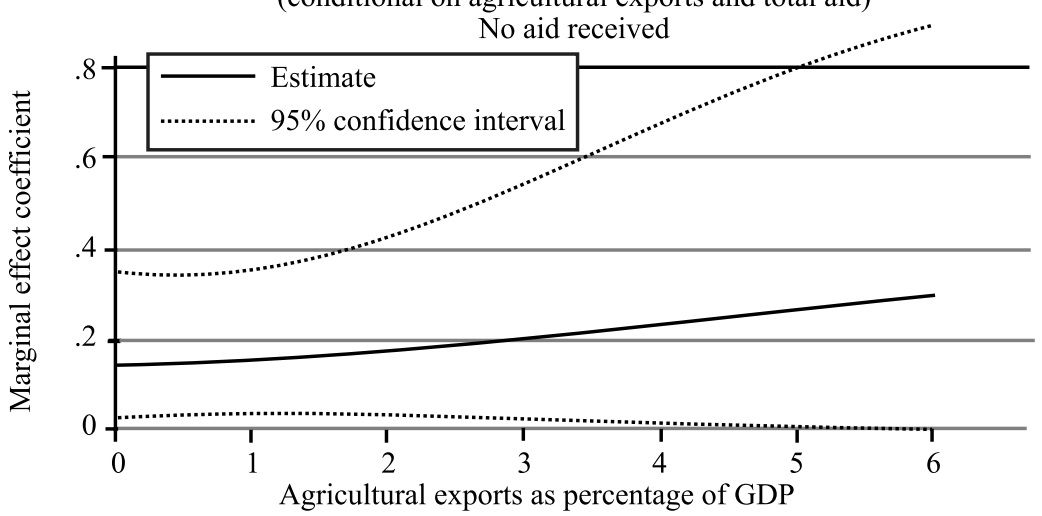

B. Predicted probability of a conflict onset during an agricultural shock (conditional on agricultural exports and total aid)

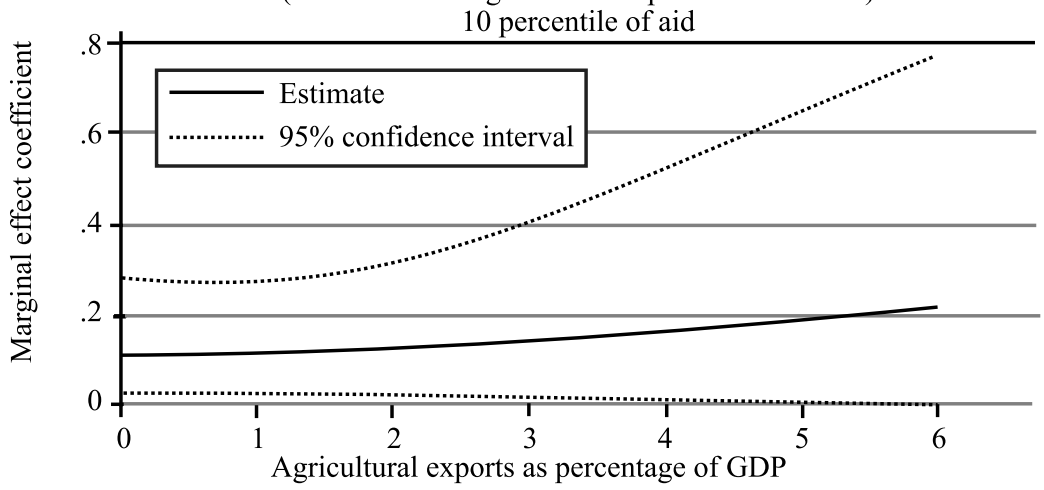

C. Predicted probability of a conflict onset during an agricultural shock (conditional on agricultural exports and total aid)

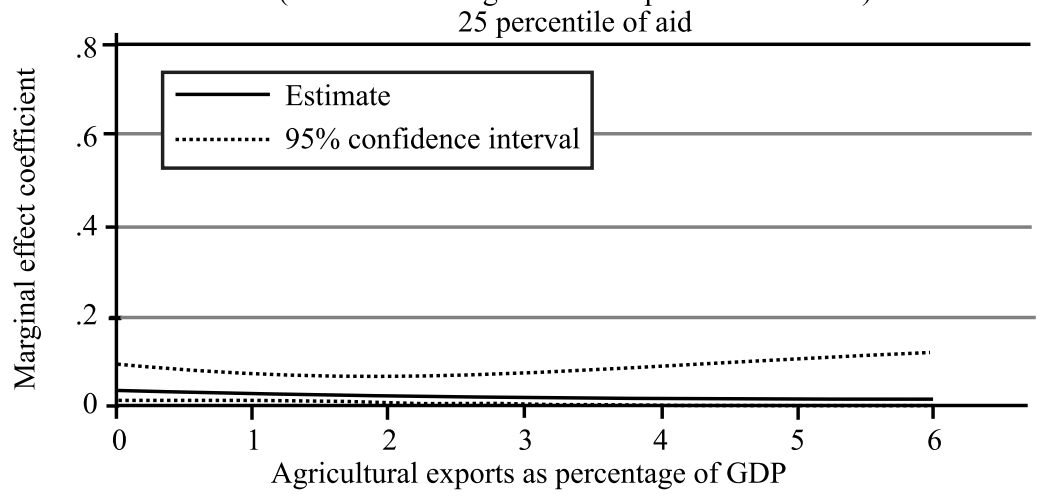

FIGURE 4. Predicted probability of conflict after agricultural shocks 
ever, the likelihood of conflict in the presence of an economic shock diminishes, becoming negligible at median levels of aid and above (Figure 4C).

\section{Conclusion}

The recent findings in civil war literature paint a bleak picture for the prospects of sustained domestic stability in low-income countries. Peace in these countries, which is already imperiled by their low levels of economic development, is further jeopardized by their additional susceptibility to conflict as a result of economic shocks. We suggest that foreign aid can provide low-income countries a potential mechanism by which they may mitigate the risk of conflict during times of severe economic downturns. In particular, foreign aid can help the recipient governments maintain their level of spending or at least minimize the decrease in government spending by buffering government revenues from the economic shocks.

One of the striking results of this study is how small amounts of aid can have large pacifying effects. Small increases in aid, particularly at low initial levels of allocation, can help ameliorate the conflict-generating aspects of an economic shock (Figures 2A and 2B). Although aid may not be given primarily for conflictprevention purposes, its efficiency at providing this service to the recipient governments is definitely a positive externality, and a relatively inexpensive one at that.

Important policy implications follow. Collier and Goderis show that foreign aid is not usually targeted at shock-prone countries. ${ }^{102}$ Our findings suggest that policymakers may want to consider aid reallocation toward shock-prone countries to improve its effectiveness. Another area in which policymakers could be responsive is to allow recipient governments some discretion in the use of foreign assistance even under strict conditionality agreements during times of economic shock. If the arguments that aid has limited fungibility are correct, then this would be one case where willingly allowing governments to use these funds for alternative purposes could have large short-term benefits. This could be achieved through more frequent use of programmatic aid (budgetary support) over project aid (specific investment loans) in shock-prone countries. ${ }^{103}$

From a normative perspective, our focus on aid's short-term effects and the mediating effect of shocks means that we do not take a position on the arguments addressing aid's potential long-term effects on recipient countries. For example, we do not necessarily disagree with Bueno de Mesquita and Smith that aid could have potentially pernicious long-term effects on recipients. ${ }^{104}$ From our perspective, the effect we demonstrate can be considered normatively good if aid can

102. Collier and Goderis 2009a, 445.

103. Winters 2010.

104. Bueno de Mesquita and Smith 2009. 
help prevent, in the short-term, a country's descent into conflict from a short-term economic shock. This effect may need to be balanced against the long-term incentives addressed in the literature, but our finding that small amounts of aid can have significant impacts may be beneficial in this regard. The distribution of relatively small amounts of aid that could help governments buffer against shocks in the short term but not necessarily change other types of domestic political incentives in the long run may be a way to reconcile the two positions.

One possible avenue by which the two competing positions may also be reconciled is to examine the effects of micro-level patterns of aid distribution on conflict following an economic shock. We adopt the assumption that governments utilize aid in a manner they believe affords them the best opportunity to maintain office, and measure gross aid allocations rather than subnational distributions. As a general rule this is logical; but if there are particular circumstances in which the spending incentives are more antithetical to democracy or good governance generally, then it would be fruitful to examine how particular subnational spending patterns might affect the likelihood of conflict onset. If certain types of spending were found to be overtly harmful to democracy and also yielded little benefit regarding conflict prevention, then the pernicious effects of aid may be avoided while still allowing for aid to reduce conflict propensity following a shock. However, these are questions best left for future research. For now our focus is on showing that foreign aid can attenuate the risk of civil conflict during economic hardship.

\section{References}

Acemoglu, Daron, and James A. Robinson. 2006. Economic Origins of Dictatorship and Democracy. New York: Cambridge University Press.

Alesina, Alberto, Filipe R. Campante, and Guido Tabellini. 2008. Why Is Fiscal Policy Often Procyclical? Journal of the European Economic Association 6 (5):1006-36.

Azam, Jean-Paul. 2001. The Redistributive State and Conflicts in Africa. Journal of Peace Research 38 (4):429-44.

Bearce, David H., and Daniel C. Tirone. 2010. Foreign Aid Effectiveness and the Strategic Goals of Donor Governments. Journal of Politics 72 (3):837-51.

Beck, Nathaniel, Jonathan N. Katz, and Richard Tucker. 1998. Taking Time Seriously: Time-SeriesCross-Section Analysis with a Binary Dependent Variable. American Journal of Political Science 42 (4):1260-88.

Berry, William D., Matt Golder, and Daniel Milton. 2009. The Importance of Fully Testing Conditional Theories Positing Interaction. Unpublished manuscript, Florida State University, Tallahassee.

Boone, Peter. 1996. Politics and the Effectiveness of Foreign Aid. European Economic Review 40 (2):289-329.

Brambor, Thomas, William Roberts Clark, and Matt Golder. 2006. Understanding Interaction Models: Improving Empirical Analyses. Political Analysis 14 (1):63-82.

Brückner, Markus, and Antonio Ciccone. 2010. International Commodity Prices, Growth, and the Outbreak of Civil War in Sub-Saharan Africa. Economic Journal 120 (544):519-34.

Bueno de Mesquita, Bruce, and Alastair Smith. 2009. A Political Economy of Aid. International Organization 63 (2):309-40.

2010. Leader Survival, Revolutions, and the Nature of Government Finance. American Journal of Political Science 54 (4):936-50. 
Bueno de Mesquita, Bruce, Alastair Smith, Randolph M. Siverson, and James D. Morrow. 2003. The Logic of Political Survival. Cambridge, Mass.: MIT Press.

Burnside, Craig, and David Dollar. 2000. Aid, Policies, and Growth. American Economic Review 90 (4):847-68.

Carter, David B., and Curtis S. Signorino. 2010. Back to the Future: Modeling Time Dependence in Binary Data. Political Analysis 18 (3):271-92.

Chassang, Sylvain, and Gerard Padró i Miquel. 2009. Economic Shocks and Civil Wars. Quarterly Journal of Political Science 4 (3):211-28.

Collier, Paul, and Jan Dehn. 2001. Aid, Shocks, and Growth. Working Paper 2688. Washington, D.C.: World Bank.

Collier, Paul, V.L. Elliott, Håvard Hegre, Anke Hoeffler, Marta Reynal-Querol, and Nicholas Sambanis. 2003. Breaking the Conflict Trap: Civil War and Development Policy. Washington, D.C.: World Bank/Oxford University Press.

Collier, Paul, and Benedikt Goderis. 2009a. Does Aid Mitigate External Shocks? Review of Development Economics 13 (3):429-51.

-2009b. Structural Policies for Shock-Prone Developing Countries. Oxford Economic Papers 61 (4):703-26.

Collier, Paul, and Jan Willem Gunning. 1999. Trade Shocks in Developing Countries. 2 vols. New York: Oxford University Press.

Collier, Paul, and Anke Hoeffler. 2002. Aid, Policy and Peace: Reducing the Risks of Civil Conflict. Defence and Peace Economics 13 (6):435-50.

. 2004. Greed and Grievance in Civil War. Oxford Economic Papers 56 (4):563-95.

- 2007. Unintended Consequences: Does Aid Promote Arms Races? Oxford Bulletin of Economics and Statistics 69 (1):1-27.

Combes, Jean-Louis, and Patrick Guillaumont. 2002. Commodity Price Volatility, Vulnerability and Development. Development Policy Review 20 (1):25-39.

Dube, Oeindrila, and Juan F. Vargas. 2008. Commodity Price Shocks and Civil Conflict: Evidence from Colombia. Working Paper. Cambridge, Mass.: Harvard University.

Dunning, Thad. 2004. Conditioning the Effects of Aid: Cold War Politics, Donor Credibility, and Democracy in Africa. International Organization 58 (2):409-23.

Easterly, William. 2003. Can Foreign Aid Buy Growth? Journal of Economic Perspectives 17 (3): 23-48.

Eriksson, Mikael, Peter Wallensteen, and Margareta Sollenberg. 2003. Armed Conflict, 1989-2002. Journal of Peace Research 40 (5):593-607.

Fearon, James D. 2008. Economic Development, Insurgency, and Civil War. In Institutions and Economic Performance, edited by Elhanan Helpman, 292-328. Cambridge, Mass.: Harvard University Press.

- 2010. Governance and Civil War Onset. World Development Report 2011 Background Paper. Available at 〈http://wdr2011.worldbank.org/governance-and-civil-war-onset〉. Accessed 25 April 2012.

Fearon, James D., and David D. Laitin. 2003. Ethnicity, Insurgency, and Civil War. American Political Science Review 97 (1):75-90.

Feeny, Simon. 2007. Foreign Aid and Fiscal Governance in Melanesia. World Development 35 (3): 439-53.

Feyzioglu, Tarhan, Vinaya Swaroop, and Min Zhu. 1998. A Panel Data Analysis of the Fungibility of Foreign Aid. World Bank Economic Review 12 (1):29-58.

Finkel, Steven, Aníbal Pérez-Liñán, and Mitchell Seligson. 2007. The Effects of U.S. Foreign Assistance on Democracy Building, 1990-2003. World Politics 59 (3):404-40.

Flores, Thomas E., and Irfan Nooruddin. 2009. Democracy Under the Gun: Understanding PostConflict Economic Recovery. Journal of Conflict Resolution 53 (1):3-29.

Fundanga, Caleb M. 2009. The Emergence of the Global Economic Crisis and Its Impact to Social Economic Development of Zambia. Paper presented at the Zambia Congress of Trade Unions Top Leadership Workshop, March, Lusaka, Zambia. Available at /http://www.boz.zm/publishing/ speeches/governorspresentationonglobalfinancialcrisis.pdf $\rangle$. Accessed 25 April 2012. 
Gavin, Michael, and Roberto Perotti. 1997. Fiscal Policy in Latin America. NBER Macroeconomics Annual 12:11-61.

Giugale, Marcelo M., Olivier Lafourcade, and Connie Luff, eds. 2003. Colombia: The Economic Foundation of Peace. Washington, D.C.: World Bank.

Gleditsch, Nils Petter, Peter Wallensteen, Mikael Eriksson, Margareta Sollenberg, and Håvard Strand. 2002. Armed Conflict 1946-2001: A New Dataset. Journal of Peace Research 39 (5):615-37.

Goldstone, Jack A., Robert H. Bates, David L. Epstein, Ted Robert Gurr, Michale B. Lustik, Monty G. Marshall, Jay Ulfelder, and Mark Woodward. 2010. A Global Model for Forecasting Political Instability. American Journal of Political Science 54 (1):190-208.

Goode, Richard B. 1984. Government Finance in Developing Countries. Washington, D.C.: Brookings Institution.

Green, Duncan. 2009. A Copper-Bottomed Crisis? The Impact of the Global Economic Meltdown on Zambia. Oxfam International Discussion Document. Available at 〈http://www.oxfam.org.uk/ resources/policy/economic_crisis/downloads/impact_economic_crisis_zambia.pdf $\rangle$. Accessed 25 April 2012.

Guillaumont, Patrick, and Lisa Chauvet. 2001. Aid and Performance: A Reassessment. Journal of Development Studies 37 (6):66-92.

Gurr, Ted Robert. 1970. Why Men Rebel. Princeton, N.J.: Princeton University Press.

Hansen, Henrik, and Finn Tarp. 2000. Aid Effectiveness Disputed. Journal of International Development 12 (3):375-98.

Hegre, Håvard, and Nicholas Sambanis. 2006. Sensitivity Analysis of Empirical Results on Civil War Onset. Journal of Conflict Resolution 50 (4):508-35.

Heston, Alan, Robert Summers, and Bettina Aten. 2006. Penn World Table Version 6.2. Philadelphia: Center for International Comparisons of Production, Income, and Prices, University of Pennsylvania.

Hudson, John, and Paul Mosley. 2001. Aid Policies and Growth: In Search of the Holy Grail. Journal of International Development 13 (7):1023-38.

Kaufman, Robert R., and Alex Segura-Ubiergo. 2001. Globalization, Domestic Politics, and Social Spending in Latin America: A Time-Series Cross-Section Analysis, 1973-97. World Politics 53 (4):553-87.

Kim, So Young. 2007. Openness, External Risk, and Volatility: Implications for the Compensation Hypothesis. International Organization 61 (1):181-216.

Kono, Daniel Yuichi, and Gabriella R. Montinola. 2009. Does Foreign Aid Support Autocrats, Democrats, or Both? Journal of Politics 71 (2):704-18.

Kosack, Stephen, and Jennifer Tobin. 2006. Funding Self-Sustaining Development: The Role of Aid, FDI, and Government in Economic Success. International Organization 60 (1):205-43.

Levi, Margaret. 2006. Presidential Address: Why We Need a New Theory of Government. Perspectives on Politics 4 (1):5-19.

Marshall, Monty G., and Keith Jaggers. 2002. Polity IV Project: Political Regime Characteristics and Transitions, 1800-2002. Dataset Users' Manual. University of Maryland, College Park.

Martins, Pedro M. G. 2007. The Impact of Foreign Aid on Government Spending, Revenue and Domestic Borrowing in Ethiopia. Working Paper 41. Brasilia, Brazil: International Poverty Centre, Brazilian Institute for Applied Economic Research.

Miguel, Edward. 2007. Poverty and Violence: An Overview of Recent Research and Implications for Foreign Aid. In Too Poor for Peace? Global Poverty, Conflict, and Security in the Twenty-first Century, edited by Lael Brainard and Derek H. Chollet, 50-59. Washington, D.C.: Brookings Institution.

Miguel, Edward, Shanker Satyanath, and Ernest Sergenti. 2004. Economic Shocks and Civil Conflict: An Instrumental Variables Approach. Journal of Political Economy 112 (4):725-53.

Morrison, Kevin M. 2009. Oil, Nontax Revenue, and the Redistributional Foundations of Regime Stability. International Organization 63 (1):107-38.

Ndulo, Manenga, Dale Mudenda, Lutangu Ingombe, and Lillian Muchimba. 2009. Global Financial Crisis Discussion Series: Zambia. ODI Global Financial Crisis Discussion Papers 10. London: Overseas Development Institute. Available at 〈http://www.odi.org.uk/resources/docs/4331.pdf〉. Accessed 25 April 2012. 
Neumayer, Eric. 2003a. The Pattern of Aid Giving: The Impact of Good Governance on Development Assistance. London: Routledge.

- 2003b. The Determinants of Aid Allocation by Regional Multilateral Development Banks and United Nations Agencies. International Studies Quarterly 47 (1):101-22.

Nielsen, Richard A., Michael G. Findley, Zachary S. Davis, Tara Candland, and Daniel L. Nielson. 2011. Foreign Aid Shocks as a Cause of Violent Armed Conflict. American Journal of Political Science 55 (2):219-32.

Nooruddin, Irfan, and Pradeep Chhibber. 2008. Unstable Politics: Fiscal Space and Electoral Volatility in the Indian States. Comparative Political Studies 41 (8):1069-91.

Nooruddin, Irfan, and Joel W. Simmons. 2006. The Politics of Hard Choices: IMF Programs and Government Spending. International Organization 60 (4):1001-33.

Pack, Howard, and Janet Rothenberg Pack. 1990. Is Foreign Aid Fungible? The Case of Indonesia. Economic Journal 100 (399):188-94.

Reinhart, Carmen M., and Kenneth S. Rogoff. 2004. Serial Default and the "Paradox" of Rich-to-Poor Capital Flows. American Economic Review 94 (2):53-58.

Remmer, Karen L. 2004. Does Foreign Aid Promote the Expansion of Government? American Journal of Political Science 48 (1):77-92.

Rudra, Nita. 2002. Globalization and the Decline of the Welfare State in Less-Developed Countries. International Organization 56 (2):411-45.

Savun, Burcu, and Scott Cook. 2010. Exogenous Shocks, Bargaining Problems, and Civil Wars. Paper presented at the 106th Annual Meeting of the American Political Science Association, September, Washington, D.C.

Schraeder, Peter J., Steven W. Hook, and Bruce Taylor. 1998. Clarifying the Foreign Aid Puzzle: A Comparison of American, Japanese, French, and Swedish Aid Flows. World Politics 50 (2):294-323.

Talvi, Ernesto, and Carlos A. Végh. 2005. Tax Base Variability and Procyclical Fiscal Policy in Developing Countries. Journal of Development Economics 78 (1):156-90.

United Nations Development Programme (UNDP). 2009. Human Development Report 2009. Overcoming Barriers: Human Mobility and Development. New York: UNDP.

Vreeland, James Raymond. 2003. The IMF and Economic Development. New York: Cambridge University Press.

- 2007. The International Monetary Fund: Politics of Conditional Lending. New York: Routledge.

White, Howard, and Tove Edstrand. 1998. Zambia. In Aid and Macroeconomic Performance: Theory, Empirical Evidence, and Four Country Cases, edited by Howard White, 222-55. New York: St. Martin's Press.

Wibbels, Erik. 2006. Dependency Revisited: International Markets, Business Cycles, and Social Spending in the Developing World. International Organization 60 (2):433-68.

Wibbels, Erik, and Moisés Arce. 2003. Globalization, Taxation, and Burden-Shifting in Latin America. International Organization 57 (1):111-36.

Winters, Matthew S. 2010. Choosing to Target: What Types of Countries Get Different Types of World Bank Projects? World Politics 62 (3):422-58.

Wooldridge, Jeffrey M. 2002. Econometric Analysis of Cross-Section and Panel Data. Cambridge, Mass.: MIT Press.

World Bank. 2002. Zambia: Country Assistance Evaluation. Report No. 25075. Washington, D.C.: World Bank. Available at 〈http://go.worldbank.org/0BH0JS6GO0〉. Accessed 25 April 2012.

Wright, Joseph. 2009. How Foreign Aid Can Foster Democratization in Authoritarian Regimes. American Journal of Political Science 53 (3):552-71.

Zeger, Scott L., Kung-Yee Liang, and Paul S. Albert. 1988. Models for Longitudinal Data: A Generalized Estimating Equation Approach. Biometrics 44 (4):1049-60. 